\title{
SEASONAL DISTRIBUTION OF ZOOPLANKTON COMPOSITION AND ABUNDANCE IN A SUB-TROPICAL MANGROVE AND SALT MARSH ESTUARY
}

\author{
Abu Hena M. K. ${ }^{*}$, Japar Sidik B. ${ }^{2}$, Idris M. H. ${ }^{3}$, Johan I. ${ }^{1}$, Nesarul N. H. ${ }^{1,4}$, Aysha A. ${ }^{4}$ and Islam M. \\ S. 4 \\ ${ }^{1}$ Department of Animal Science and Fishery, Faculty of Agriculture and Food Sciences, Universiti Putra Malaysia Bintulu \\ Sarawak Campus, Nyabau Road, Post Box No. 396, 97008 Bintulu, Sarawak, Malaysia, *Email: hena71 @yahoo.com \\ ${ }^{2}$ Department of Biology, Universiti Putra Malaysia, 43400 UPM Serdang, Selangor D. E., Malaysia \\ ${ }^{3}$ School of Fisheries and Aquaculture Sciences, Universiti Malaysia Terengganu, 21030 Kuala Terengganu, Terengganu Darul \\ Iman, Malaysia \\ ${ }^{4}$ Institute of Marine Sciences and Fisheries, University of Chittagong, Chittagong-4331, Bangladesh \\ Received : 25 Oct 2016 \\ Revised : 18 Nov 2016 \\ Accepted : 25 Oct 2016
}

\begin{abstract}
Zooplankton composition and abundance at two stations located in exposed (station I) and protected (station II) areas of Bakkhali sub-tropical estuary, Cox's Bazar, Bangladesh were investigated monthly from January 2006 to December 2006. Thirty-three zooplankton taxa were identified. The major groups of zooplankton encountered were Copepoda, Chaetognatha, Mysidaceae, Luciferidae, Amphipoda, Acetes, Hydromedusae, Cladoceran, Decapod and fish larvae. The percent composition of Copepoda was the highest (79.584.8\%) among zooplankton groups followed by Chaetognatha (5.5-6.0\%) and Mysidaceae (3.3-6.8\%). The abundance of zooplankton was relatively higher (87674individuals $/ \mathrm{m}^{3}$ ) in protected (mangrove) as compared to exposed (salt marsh; 68719 individuals $/ \mathrm{m}^{3}$ ) site during the study period. Canonical Correspondence Analysis indicated that the abundance of copepods was influenced by rainfall, water temperature and transparency in this estuarine environment, and considered coastal and estuarine dominant.
\end{abstract}

Key words: Zooplankton, Mangrove, Salt marsh, Estuary and sub-tropical

\section{INTRODUCTION}

Coastal area of sub-tropical country is characterized by sprawling estuaries predominated by saltmarshes and mangroves [1]. These areas are generally known to trap essential nutrients for primary productivity, which supports high abundance of secondary production, i.e. zooplankton [2]. As zooplankton forms an intermediate link between primary and tertiary productions in the food chain, high zooplankton production in saltmarsh and mangrove dominated estuaries is therefore serves as an important feeding ground for many commercially important finfish and shellfish [3-6].
Although zooplankton plays a key role transferring energy from primary producer (s) to predatory fish in the food chain, the study on zooplankton biodiversity in mangroves and saltmarshes of Bangladesh is meager. Any investigation on zooplankton in mangrove and saltmarsh ecosystems is considered an important study to the country especially for fishery sustainability. Therefore, the objective of the present study is to investigate the zooplankton abundance and composition as affected by environmental parameters (i.e. rainfall, water temperature, $\mathrm{pH}$, salinity, dissolved oxygen, total chlorophyll, total suspended solid and evaporation rate) throughout a one-year period in the sub-tropical Bakkhali estuary, Cox's Bazar, Bangladesh. 


\section{MATERIALS AND METHODS}

\section{Study area}

The study was conducted in Bakkhali estuary at Cox's Bazar district, Bangladesh located between $20^{\circ} 85^{\prime} 40^{\prime \prime}$ and $21^{\circ} 46^{\prime} 92^{\prime \prime} \mathrm{N}$ latitude and $91^{\circ} 96^{\prime}$ $60^{\prime \prime}$ to $92^{\circ} 34^{\prime}$ 37" E longitude (Fig. 1). The Bakkhali river originated from the
North Arakan Mountain and flows over the Cox's Bazar city and into the Bay of Bengal. Tidal regime of Bakkhali estuary is semi-diurnal and climatology is monsoonal dictated. The river is characterized by muddy and sandy bottom [22-24]. Mangroves and saltmarshes vegetated at the both sides along the river.

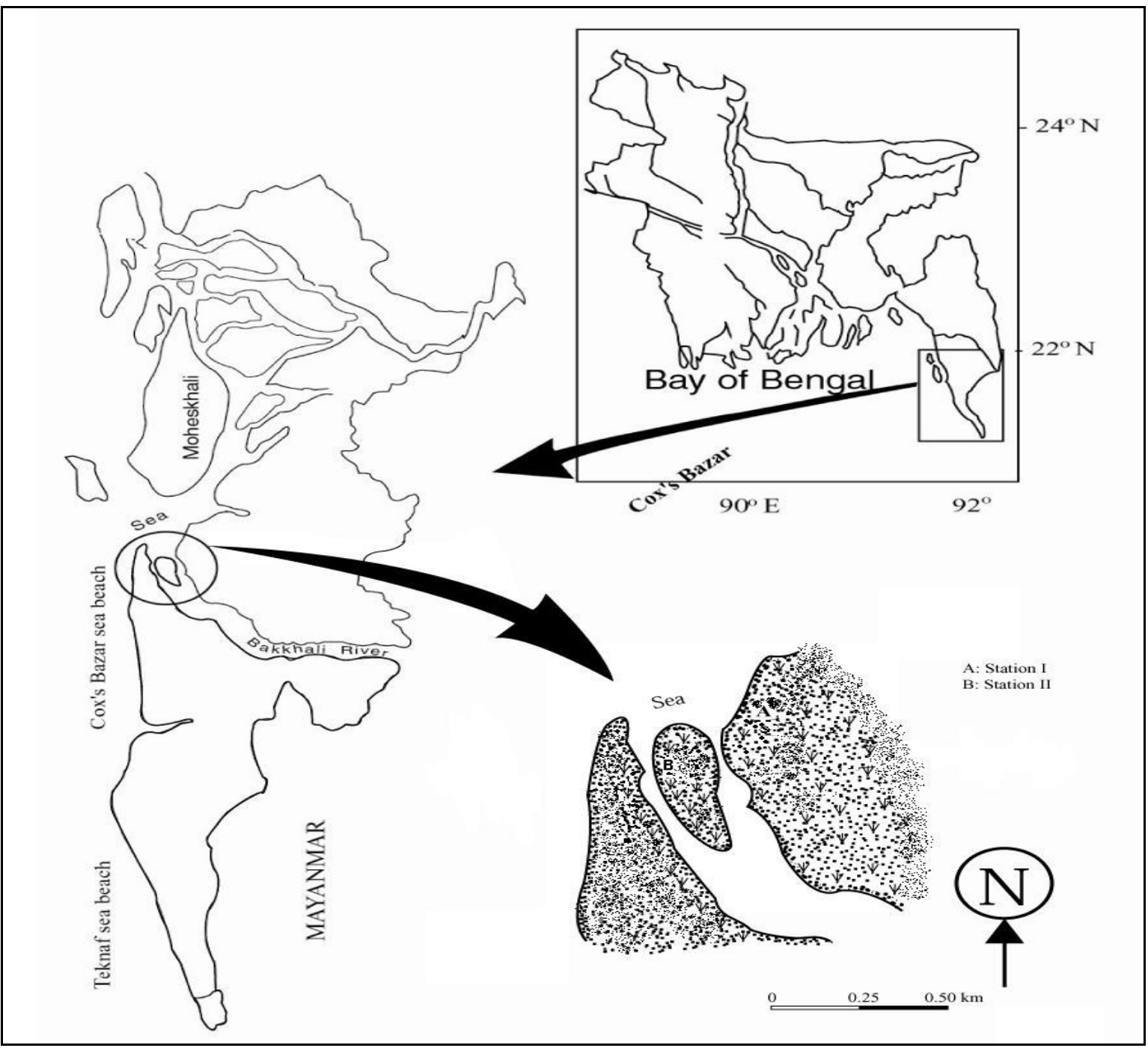

Figure 1: Study area map showing the sampling location $(A=$ station $I$ and $B=s$ tation II) in Bakkhali estuary, Cox's Bazar, Bangladesh. 


\section{Collection and analysis of zooplankton}

Monthly sampling was conducted to collect the zooplankton and hydrological parameters during spring high tide in two different mangrove and salt marsh habitats from January 2006 to December 2006. Both the mangrove and salt marsh are submerged only during high tide, hence, sample time was selected during high water. Two sampling stations i.e., Station I (exposed to the sea; mainly salt marsh) and Station II (protected from sea; mainly mangroves) areas were selected for the collection of zooplankton and hydrological samples. The geographical locations of the investigated area were approximately $21^{\circ} 28.667^{\prime} \mathrm{N}$ and $91^{\circ}$ $58.426^{\prime} \mathrm{E}$ for station I and $21^{\circ} 28.356^{\prime} \mathrm{N}$ and $91^{\circ} 58.350^{\prime} \mathrm{E}$ for station II, which is flooded and exposed twice daily during high and low tides. Mixed stand and mono-specific forms of mangrove and salt marsh on sandy and muddy bottom substrate are found in in Station II, while station I was only covered salt marsh. The estuary is approximately $0.5 \mathrm{~km}$ wide and $>10 \mathrm{~m}$ deep at its mid point with maximum amplitude of $3 \mathrm{~m}$ at high spring tide [23].

Zooplankton were collected (three replicates in each sample time and station) from $<0.6 \mathrm{~m}$ below the surface water using a conical shaped $90 \mathrm{~cm}$ long plankton net (made of bolting silk) similar to that described by Mahmood and Khan [25] of $335 \mu \mathrm{m}$ mesh size, attached with a circular metal frame with $35 \mathrm{~cm}$ mouth opening and fitted with metal bucket at the end cod. A digital flow meter (FMC, 0.3) was fixed at the mouth of the net to record the amount of water filtered through the net during collection [25]. The sampling was conducted by a boat plied with the help of oars. The zooplankton samples were preserved in 5\% formalin on board and brought back to the Institute of Marine Science and Fisheries laboratory.

\section{Laboratory analysis}

In the laboratory, the specimens of each sample were sorted into different taxonomic groups using a dissecting microscope (Optika-ST302LF). Major zooplankton groups were separated following those described by Gosner [26], Omori [27], Newell and Newell [28], Elias [29], Omori and Ikeda [30] and Ahmed [31]. Diversity of zooplankton was calculated either by complete count or by sub-sample method when the catches were too large and converting their numerical abundance to individuals per cubic meter.

\section{Collection and analysis of environmental parameters}

Water temperature, transparency, $\mathrm{pH}$ and salinity were measured in situ using mercury thermometer, secchi disk (30 $\mathrm{cm}$ in diameter), $\mathrm{pH}$ meter (Hanna, Italy) and refractometer (OSK, Japan), respectively. Rainfall and evaporation data were obtained from the meteorological department of Cox's Bazar. Water samples were collected in three replicates, and poured into a prelabeled 500-ml plastic bottle for total suspended solid (TSS) and total chlorophyll determination. All water samples were immediately kept in an 
icebox and brought back to the laboratory for further analysis. To determine dissolved oxygen (DO) of surface water from two different stations, water samples were collected in six BOD bottles of different volumes.

Collected samples from BOD bottles were fixed in the field by adding $1 \mathrm{ml}$ of manganese sulphate $\left(\mathrm{MnSO}_{4}\right)$ solution and $1 \mathrm{ml}$ of alkaline $\mathrm{ml}$ potassium iodide (KI) and the fixed water samples were transported for further analysis following the Azid modification of Winkler's method. Dissolved oxygen was measured following the procedure described by Lind [32]. Total Suspended Solid was detected following the procedure described by Andrews et al. [33] and total chlorophyll was detected by the procedure described by Arnon [34].

The Shannon-Wiever index $\left(H^{\prime}\right)$ was used to summarize the information on the relative abundances of zooplankton species found within the study area. The Shannon diversity index is commonly used to describe the diversity of the particular community and as an indicator for the assessment of an ecosystem with regards to abundance and diversity [35]. Shannon diversity index $\left(H^{\prime}\right)$ and evenness $(E)$ were calculated for each of the sample bases on the following formula Magurran [36]:

$$
H^{\prime}=-\sum \mathrm{p} i \ln \mathrm{p} i
$$

Where $\mathrm{p} i$ is the proportional abundance of the $i$ th species $=\left(\frac{\mathrm{n} i}{\mathrm{~N}}\right)$

$\mathrm{n} i=$ number of individual species counted

$\mathrm{N}=$ total number of species

$E=\frac{H^{\prime}}{\ln S}$

Where $\ln S$ is the natural $\log$ of the total number species

CANOCO 4.5 version software was used for Canonical Correspondence Analysis (CCA), performing step-wise regression [37]. Using CCA routine executed in CANOCO linking log transformed zooplankton density with environmental parameters $(\mathrm{pH}$, water temperature, dissolved oxygen, total suspended solid, total Chlorophyll, salinity, rainfall, evaporation) for different months. A Monte Carlo permutation test (unrestricted) was conducted to assess the significance of zooplankton species-environment relationships for all the collected made at stations I and II.

\section{RESULTS}

\section{Environmental parameters}

Except transparency, seasonal monsoonal variations of other environmental parameter like water salinity, dissolved oxygen, total chlorophyll and TSS were observed in this estuarine area (Table 1). 
Table 1. Summary results of two-way ANOVA and post-hoc Tukey HSD tests on various abiotic factors and zooplankton groups (mean $\pm \mathrm{SD})(* \mathrm{P} \leq 0.05, * * \mathrm{P} \leq 0.01$, ns $=$ not significant).

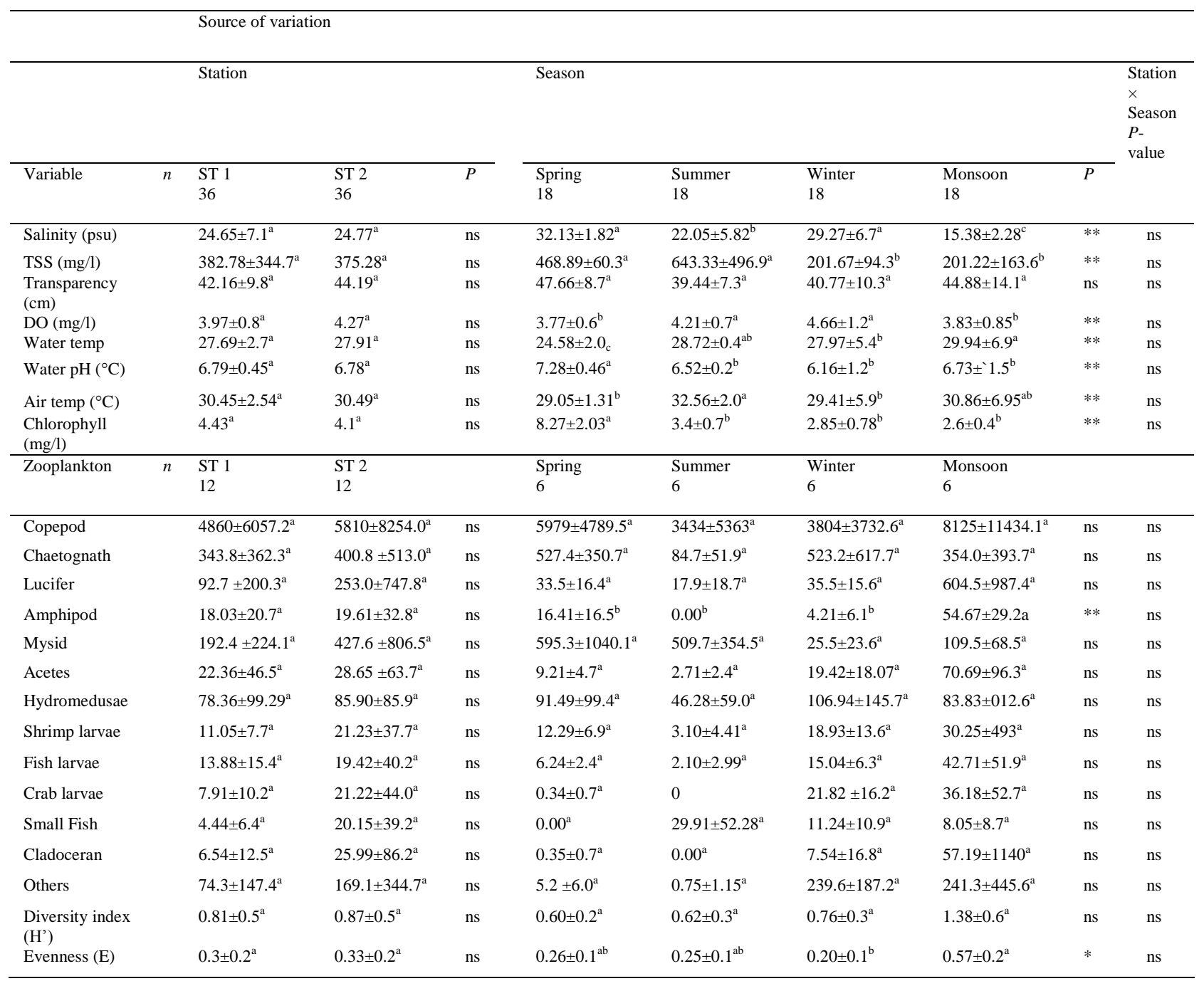


The lowest air $\left(26.17^{\circ} \mathrm{C}\right)$ and surface water $\left(25.17^{\circ} \mathrm{C}\right)$ temperatures were recorded during December and the highest (34.5 ${ }^{\circ} \mathrm{C}$ for air and $3^{\circ} \mathrm{C}$ for water) in July. The surface water temperature showed an increasing trend from May to July and it was low during the winter from November to January. Temperature was influenced by the solar radiation, monsoon and evaporation. The water $\mathrm{pH}$ values during the study period were found slightly acidic to alkaline and ranged from 6.50 to 7.90 , while salinity values was found between $14.50 \mathrm{psu}$ and $34.50 \mathrm{psu}$. Salinity changes are related to monsoonal climate, rainfall and freshwater runoff in this estuarine ecosystem. Seasonal changes in salinity were noticed and found higher (34.50 psu) in February and lower (14.40 psu) in August. The average DO ranged from 3.07 to $6.48 \mathrm{mg} / 1$ for both the stations during the study period. Similarities existed between DO and total chlorophyll. Total chlorophyll was higher (10.02-10.08 $\mathrm{mg} / \mathrm{l}$ ) during January and February, and decreased from March to October in both the stations.
An inverse relationship was found between the transparency and TSS. The highest transparency $(59 \mathrm{~cm})$ of water was found in February and lowest $(32.67 \mathrm{~cm})$ was recorded in October in this estuarine environment. The evaporation rate was higher in April, while lower in December.

The first canonical axis accounted for $47.35 \%$ and, second axis accounted for the $36.35 \%$ of the variance in the zooplankton abundance. Thus first two axes cumulatively explain $83.7 \%$ of the variance. CCA model confirmed that key abiotic factors notably TSS, total chlorophyll and DO highly correlated with individual group of zooplankton abundance. For example, water characteristics such as TSS (eigen value; 0.69) and Chlorophyll (eigen value; 0.58) were found to be highly correlated with first ordination axis. Besides, water characteristics like DO (eigen value; -0.61) were found to be negatively correlated with the second ordination axis (Fig 2). Zooplankton group, Mysid was found to be closely associated with chlorophyll content of water, and crab larvae seem to have close association with water temperature. 


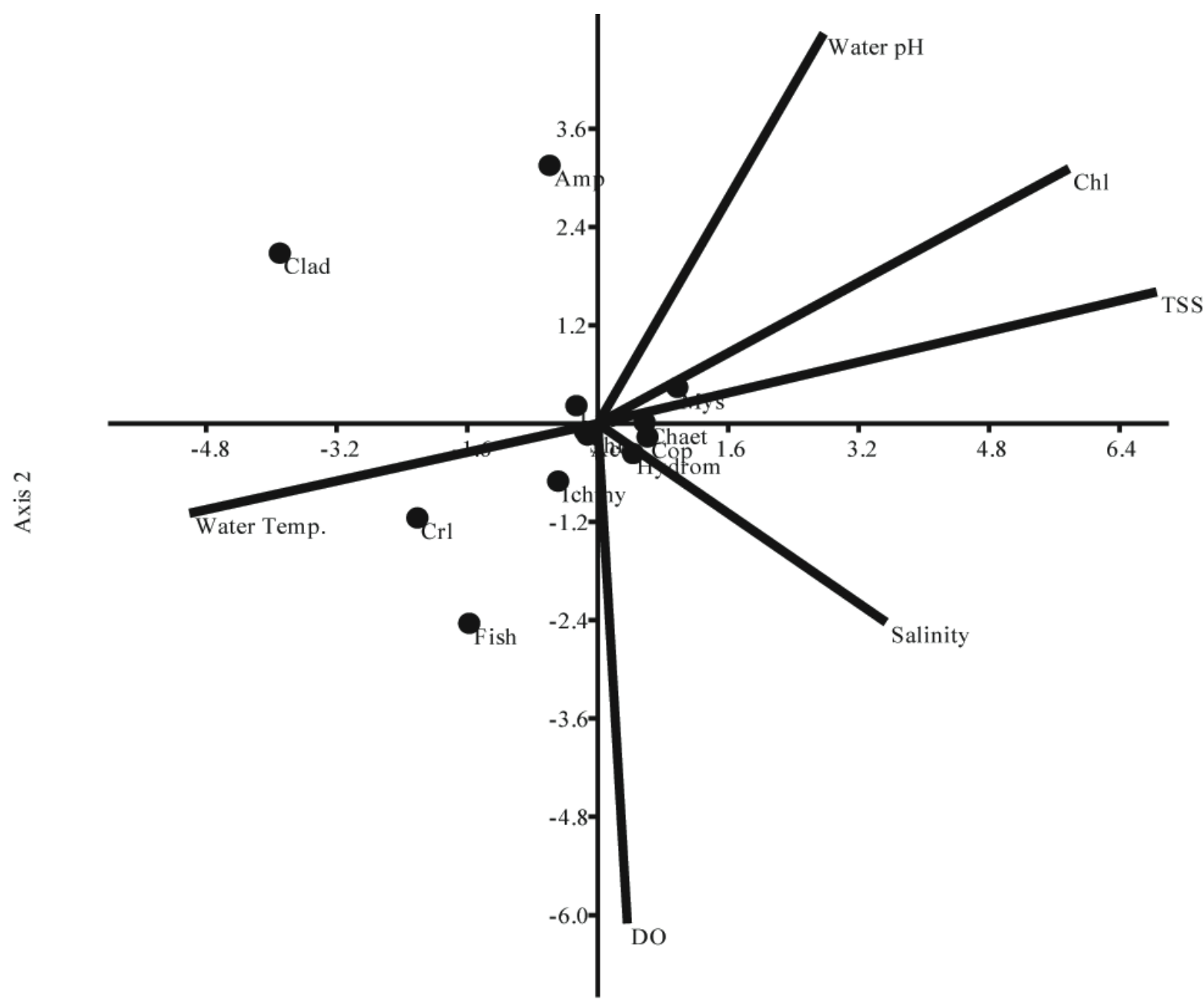

Axis 1

Figure 2. CCA showing scatter plot for zooplankton density vs 12 months environmental parameters at the mangrove and salt marsh estuarine habitats of Bakkhali, Cox's Bazar.

\section{Zooplankton abundance and composition}

A total of 33 zooplankton belonging to diverse group i.e., Copepod, Chaetognatha, Lucifer, Amphipod, Mysid, Aectes, Hydromedusae, Shrimp larvae, Ichthyoplankton, Crab larvae and Cladocera were recorded (Table 2). The ranges of population densities of zooplankton were; 684-22284 and 305-34391 individual $/ \mathrm{m}^{3}$ at stations I and II, respectively. The total number of zooplankton was found higher $\left(87674.11\right.$ individuals $\left./ \mathrm{m}^{3}\right)$ in station II compared to station I $\quad(68718.62$ individuals $/ \mathrm{m}^{3}$ ). The minimum zooplankton density was recorded in June and July (monsoon) and maximum was in September (post monsoon) at both stations I and II (Fig 3). Species diversity index variations were; 0.17-1.68 (station I) and 0.22-1.97 (station II). The ranges of evenness were; 0.06-0.69 and 0.09-0.82 at stations I and II, respectively, and significantly different between winter and monsoon. Zooplankton diversity was high during July-August compared to the other months in both the stations I and II. Copepods were dominant groups in both sampling stations followed 
by Mysidaceae and Chaetognatha. The percent composition of copepods in the total zooplankton was 79.53-84.8\%,
Chaetognatha $5.5-6.0 \%$ and mysidaceae consists of $3.3-6.8 \%$ in both the sampling stations of Bakkhali estuary (Table 3).

Table 2. Major groups of zooplankton in the Bakkhali estuary Cox's Bazar.

\begin{tabular}{|c|c|}
\hline Major Groups & Zooplankton \\
\hline Copepoda & $\begin{array}{l}\text { Acartia } \mathrm{sp} . \\
\text { Labidocera } \mathrm{sp} . \\
\text { Calanus } \mathrm{sp} . \\
\text { Centroapges } \mathrm{sp} . \\
\text { Oithona } \mathrm{sp} . \\
\text { Calanopia } \mathrm{sp} . \\
\text { Eucalanus } \mathrm{sp} .\end{array}$ \\
\hline Chaetognatha & $\begin{array}{l}\text { Sagitta enflata } \\
\text { Sagitta hispida } \\
\text { Sagitta delicata }\end{array}$ \\
\hline Lucifera & $\begin{array}{l}\text { Lucifer typus } \\
\text { Lucifer orientalis }\end{array}$ \\
\hline Amphipoda & Amphipod (O) \\
\hline Mysidaceae & Mysidae (F) \\
\hline Acetes & $\begin{array}{l}\text { Acetes chinensis } \\
\text { Acetes indicus }\end{array}$ \\
\hline Hydromedusae & $\begin{array}{l}\text { Aequorea sp. } \\
\text { Aurelia sp. } \\
\text { Rhizostomeae sp. } \\
\text { Beroe sp. }\end{array}$ \\
\hline Shrimp Larvae & $\begin{array}{l}\text { Penaeus sp. } \\
\text { Leptocarpus sp. } \\
\text { Sergestes sp. }\end{array}$ \\
\hline Ichtyoplankton & $\begin{array}{l}\text { Mugil sp. } \\
\text { Liza sp. } \\
\text { Coilia sp. } \\
\text { Johnius sp. } \\
\text { Lepturacanthus sp. } \\
\text { Escualosa sp. }\end{array}$ \\
\hline Crab Larvae & $\begin{array}{l}\text { Scylla sp. } \\
\text { Neptunus sp. } \\
\text { Portunus sp. } \\
\text { Evadne sp. }\end{array}$ \\
\hline
\end{tabular}




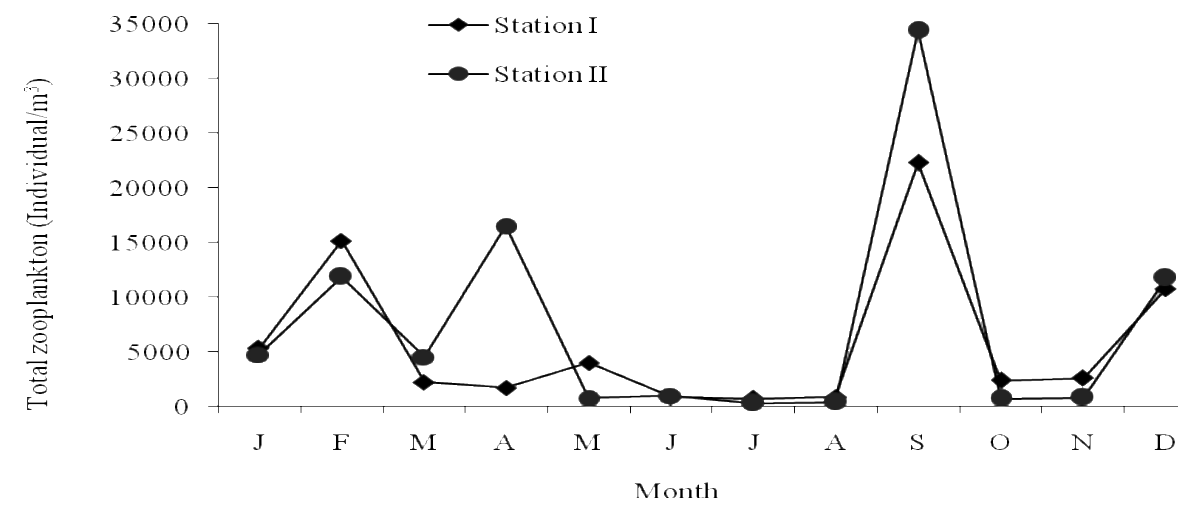

Figure 3. Abundance of monthly total zooplankton (individuals $/ \mathrm{m}^{3}$ ) of both sampling stations in the Bakkhali estuary.

Table 3. Mean abundance (individuals $/ \mathrm{m}^{3}$ ) and species composition (\%) of zooplankton in the mangrove and salt marsh habitat of Bakkhali.

\begin{tabular}{lllll}
\hline Group & \multicolumn{3}{l}{ Station I } & Station II \\
\cline { 2 - 5 } & Mean & $\%$ & Mean & $\%$ \\
\hline Copepoda & 4860.80 & 84.88 & 5810.34 & 79.53 \\
Chaetognatha & 343.81 & 6.00 & 455.80 & 6.55 \\
Lucifera & 102.70 & 1.81 & 253.00 & 3.46 \\
Amphipoda & 28.03 & 0.50 & 19.61 & 0.27 \\
Mysidaceae & 192.36 & 3.36 & 500.56 & 6.85 \\
Aectes & 32.36 & 0.58 & 28.65 & 0.39 \\
Hydromedusae & 78.36 & 1.37 & 85.90 & 1.18 \\
Shrimp larvae & 21.05 & 0.38 & 21.23 & 0.29 \\
Ichthyoplankton & 23.88 & 0.43 & 19.41 & 0.27 \\
Crab larvae & 17.91 & 0.33 & 19.46 & 0.27 \\
Fish & 14.44 & 0.26 & 20.15 & 0.28 \\
Cladoceran & 26.18 & 0.46 & 25.99 & 0.36 \\
\hline
\end{tabular}

In zooplankton composition, salinity and TSS influenced Amphipoda, while the composition of small fish and Mysidaceae were affected by water $\mathrm{pH}$, air temperature and evaporation rate (Table 4; Fig 2). The composition of Copepoda, Lucifera, Acetes, Cladoceran relied on water temperature, rainfall and water transparency. Other zooplankton species i.e., Chaetognata, Hydromedusae, shrimp larvae, crab larvae and Icthyoplankton were associated with dissolved and total chlorophyll content of water in this estuarine environment (Fig 2). 
Table 4. Results of the main ordination for the CCA on the relationship between zooplankton abundance and water parameters in Bakkhali estuary.

\begin{tabular}{lccc}
\hline & Axis 1 & Axis 2 & Axis 3 \\
\hline Water pH & 0.28 & 0.48 & -0.07 \\
Water Temp & -0.50 & -0.11 & 0.39 \\
DO & 0.04 & -0.61 & -0.45 \\
TSS & 0.69 & 0.16 & 0.36 \\
Chl & 0.58 & 0.31 & -0.23 \\
Salinity & 0.35 & -0.24 & -0.13 \\
Eigen values & 0.05 & 0.04 & 0.009 \\
Percentage of variance & 47.35 & 36.35 & 8.83 \\
Cumulative variance & 47.35 & 83.7 & 92.53 \\
\hline
\end{tabular}

\section{DISCUSSION}

Zooplankton are important in assessing the health of estuarine and coastal ecosystems. The estuarine zooplankton found in this study area bears strong similarities to that of Satkhira mangrove estuary [38]. Twelve taxonomic groups of zooplankton were found in the mangrove and salt marsh habitats of the estuarine area of Bakkhali, Cox's Bazar. This value was higher than the recorded number of zooplankton taxa (six) by Ali et al. [39]. This may be attributed to the tidal current, food availability, wind direction and river discharge that govern the diversity of zooplankton in the estuarine environment [40]. According to Ali et al. [39], the maximum abundance of zooplankton was observed during the monsoon while minimum in autumn and winter. In contrast, the present study was recorded the maximum density of zooplankton during the post monsoon and the minimum was during monsoon in this estuarine environment. Zooplankton composition and diversity demonstrated a seasonality that differed from that recorded in the mangrove and salt marsh dominant estuary and Moheskhali Channel, Bay of Bengal. In estuarine zooplankton, especially copepods are reported to be declined due to low salinities caused by freshwater runoff from river during rainy season and immediately increase thereafter during post monsoon, it is accompanied by the peak zooplankton abundance [40]. This is the case in the mangrove and salt marsh dominant estuary of Bakkhali, Cox's Bazar.

The total number of zooplankton was relatively higher $\left(87674.11\right.$ individuals $\left./ \mathrm{m}^{3}\right)$ in station II (protected area) compared to station I (exposed; 68718.62 individuals $/ \mathrm{m}^{3}$ ) during 12 months study period. As evident from the present study, the abundance of zooplankton was high in the protected mangrove and salt marsh area in Bakkhali estuary. Their presence varied within habitats similar to the 
observation made by Zafar and Mahmood [14] and Ali et al. [39]. This variation may be due to the effects of different environmental factors in the estuarine ecosystems. In fact in estuaries, the seasonal patterns of zooplankton abundance and distribution are complex and extremely variable [41-43]. Studies revealed that zooplankton communities are generally prefer sheltered, soft muddy areas rich in organic debris and nutrients derived from estuarine vegetations [44-45]. Such ideal ecological condition of protected area in Bakkhali estuary probably favors the maximum abundance of zooplankton diversity. The low abundance of zooplankton in station I in this estuary was probably due to exposed condition from big wave with no protection from saltmarsh and mangroves, which agreed to the finding of Mahmood and Zafar [38]. However, in eutrophic or nutrient rich environments like estuary and coastal area, the abundance of dense zooplankton population is food source for fisheries resources regardless of any stages [2]. The pelagic zooplankton may become available as food for the estuary dwelling fish and shellfish when they co-exist in the same habitat. This help to build up a trophic relationship in the estuarine food web and influence the dynamic of the estuarine ecosystems.

The higher number of zooplankton in station II could probably due to the good environmental support with less energy forces and higher retention quality. This finding support those of Macnae [46] that it is a good device to support conception of how the zooplankton distribution in time and space in estuarine ecosystems provided the species and environment data matrix are suitable. The total number of copepod species was relatively lower when compared to the previous data obtained from other study areas elsewhere [47-49]. The patterns of estuarine zooplankton diversity in sub-tropical estuaries have often been noted to rise and fall with environmental parameters. Zooplankton species richness and diversity index tends to increase during monsoon period in both the stations, indicating that most of the species were of estuarine and coastal origins. However, the diversity of zooplankton could influence by upwelling and nutrient inputs from the adjacent coastal environment of Bakkhali.

In sub-tropical coastal environment, estuaries are rich with endless of plankton resources, which play an important role in the fishery sector. These plankton communities depend on different types of hydrometeorological factors in the adjacent coastal and estuarine environment. Usually, the diversity of zooplankton in the estuarine mangrove-salt marsh habitats is rich elsewhere [50-51]. This present study found that copepod is the dominant group in the abundance and composition of zooplankton, which plays an important role in this estuarine food chain. As dominant species, copepod could be useful for coastal and estuarine fishery resources in this estuary. Generally, copepod has an important role in the food web, linking primary producers and higher trophic levels in aquatic ecosystems [52].

Canonical Correspondence Analysis ordination revealed the different environmental necessities and niche differentiation among zooplankton fauna. The dominant group of zooplankton Copepoda in this estuarine environment was associated with rainfall, transparency and water temperature. In addition, the riverine estuaries studied often displayed the largest zooplankton peaks in post monsoon to winter, depending on magnitude of flushing of nutrients and the subsequent winter rainfall into the lower estuary. However, the importance of runoff to estuarine biotic response has also been recognized elsewhere previously [53]. 


\section{ACKNOWLEDGEMENTS}

The author is highly acknowledged to the Nahar Welfare Trust, Cox's Bazar for providing financial help to collect the samples and to the Laboratory of Coastal and Aquaculture Research (LECAR), Institute of Marine Sciences and Fisheries, University of Chittagong for their laboratory supports.

\section{REFERENCES}

1. Pramanik, M.A.H. (1988). Methodologies and Techniques of Studying Coastal Systems. SPARRSO case studies CARDMA, 11: 122-138.

2. Nixon, S.W., Oviatt, C.A., Frithsen, J. and Sullivan. B. (1986). Nutrients and the productivity of estuarine and coastal marine ecosystems. Journal of the Limnological Society of South Africa. 12: 43-71.

3. Gibson, R. N. (1972). The vertical distribution and deeding relationships of intertidal fish on the Atlantic coast of France. Journal of Animal Ecology. 41: 189-201.

4. Kuipers, B. R. (1977). On the ecology of juvenile plaice on a tidal flat in the Wadden sea. Netherland Journal of Sea Research. 11: 56- 101.

5. Fuller, K. (1979). Shoreline as a controlling factor in commercial shrimp production, NASA-Technical Memo. 72/72. 227 pp.

6. Ortege, S. (1986). Fish predation on gastropods on the pacific coast of Costa Rica. Journal of Experimental Marine Biology and Ecology. 97: 181192.
7. FAO. (1985). Report on tidal area study Bangladesh. Fisheries Resources Survey System FAO/UNDP BGD/79/015:32PP.

8. Chowdhury, S. M. H. (1995). Occurrence and Abundance of Zooplankton Communities with Special Reference to Commercially Important Post Larvae in the Naaf River, Bangladesh M.Sc. Thesis (Unpublished). IMS, University of Chittagong, 79 pp.

9. Zafar, M. (1995). Seasonal Influence of Zooplankton Abundance with Emphasis on PL of Macrobrachium rosenbergii in the Kutubdia Channel, Bay of Bengal. In: Proceeding of the Workshop on the Coastal Aquaculture and Environmental Management, 39$44 \mathrm{pp}$.

10. Naser, A. K.V., Siraimeetan, P. and Aboobaker, P. M. (1998). Zooplankton abundance and distribution at Minicoy lagoon, Lakshadweep, India. Indian Journal of Marine Science. 27: 346350.

11. Bhuiyan, A. L., Mohi, S. A., Khair, S. A. and Das. N. G. (1982). Macrozooplanktons of the continental shelf of the Bay of Bengal. Chittagong University Studies, Part 2. (6): 51-59.

12. Islam, M. E. (1982). Study of Zooplankton of the Karnafuli River Estuary from the Biodiversity and Environmental Points of View. M.Sc. Thesis. (Unpublished) Institute of Marine Sciences, University of Chittagong, 61-72 pp.

13. Begum, S. (1984). Temporal and Spatial Distribution of Ichthyoplankters and 
Zooplankters in the Mathamuhuri Estuary. Bangladesh. M.Sc. Project. (Unpublished). Institute of Marine Sciences, University of Chittagong, 37 pp.

14. Zafar, M. and Mahmood, N. (1989). Studies on the zooplankton communities in the Satkhira estuarine system. Chittagong University Studies, Part (2). 13(1): 115-122.

15. Hossain, R. (1989). Occurrence and Distribution of Zooplankton Community with Special Reference to Hydrometeorological Parameters in Kutubdia Channel. M.Sc. Project (Unpublished) Institute of Marine Sciences, University of Chittagong. 53 pp.

16. Habiba, U. (2001). Study on Winter Distribution of Some Zooplankton of the Buriganga River, Dhaka, Bangladesh. Term paper. $4^{\text {th }}$ year, B.Sc. (Hons). Institute of Marine Science, University of Chittagong. 3$12 \mathrm{pp}$.

17. Zafar, M. (1986). Studies on the Zooplankton Communities in the Satkhira in the Vicinity of Aquaculture Farms with Special Reference to Penaeid PL. M.Sc. Thesis (Unpublished). IMS. University of Chittagong. Bangladesh, 238 pp.

18. Sewell, R. B. S. (1912). Notes on the surface copepoda of the Bay of Bengal. Research in Indian Museum, 7: 14-116 pp.

19. Das, N. G., Bhuyain, A. L. and Miah, W. (1982). Taxonomy of calanoid copepod Candacia catula (Giesbert) from north-eastern region of the Bay of Bengal. Mahasagar-Bulletin of National Institute of Oceanography. 15(1): 53-54.

20. Das, N. G. (1993). Taxonomy and Distribution of Amphipods in the Mathamuhuri Estuary of Chakaria Sunderbans Ph.D. Thesis. Calcutta University, 333pp.

21. Khair, S. A., Bhuyain, A. L. and Das, N. G. (1979). Distribution of Schmekeria lobipes in the Karnafuli river estuary. Bangladesh Journal of Agriculture, 6 (4):36-42.

22. Abu Hena, M. K., Sharifuzzaman, M., Aftabuddin, S. and Haque, M. N. (2005). Coastal Resources Utilization and conservation Issues in Cox's Bazar, Bangladesh. STREAM Journal 4 (1): 7-10.

23. Abu Hena, M. K., Short, F. T., Sharifuzzaman, S. M., Hasan, M., Rezowan, M., Ali, M. (2007). Salt marsh and seagrass communities of Bakkhali Estuary, Cox's Bazar, Bangladesh. Estuarine and Coastal Shelf Science. 75 (1-2): 72-78.

24. Abu Hena, M. K. (2013). Seasonal changes in the Porteresia coarctata (Tateoka) beds along a sub-tropical coast. Chinese Journal of Oceanography and Limnology. 31 (1): 1-9.

25. Mahmood $\mathrm{N}$ and Khan, Y. S. A. (1988). On the Occurrence of Post Larvae and Juvenile Penaeid Prwan at Bakkhali Estuary and Adjacent Coastal Area of Cox'sBazar with Notes on Their Utilization in Aquaculture. Final Report, 
Research Programme, University Grants Commission, Dhaka.

26. Gosner, K. L. (1971). Guide to Identification of Marine and Estuarine Invertebrates, John Wiley and Sons Publisher, 673 pp.

27. Omori, M. (1975). Methods in Marine Zooplankton Ecology. John will and Sons. New York, pp 1-17.

28. Newell, G. E. and Newell, R. C. (1979). Marine Plankton a Practical Guide. 5th edition. Hutchinson and Co. Ltd. London. 244 pp.

29. Elias, S. M. (1983). Zooplankton of the Mathamuhuri Estuary with Special Reference to Shrimp and Finfish larvae. M.Sc. Thesis. (Unpublished) Institute of Marine Science, University of Chittagong, $172 \mathrm{pp}$.

30. Omori, M. and Ikeda I. (1984). Methods in Marine Zooplankton Ecology. Joho Willy and Sons. New York. 332 pp.

31. Ahmed, S. (1984). Zooplankton Communities of the Estuarine Area of Sathkhira with Special Reference to Ichthyoplankton. M.Sc. Thesis (Unpublished). Institute of Marine Science, University of Chittagong, Bangladesh. 53 pp.

32. Lind, O. T. (1979). Hand Book of Common Methods in Limnology. C.V. Mosby Company, Michigan State University press, $199 \mathrm{pp}$.

33. Andrews, W., Moore, A. and Leroy A. C. (1972). A Guide to the Study of Environment Pollution; Printed in USA.
34. Arnon, D. I. (1949). Copper enzymes in isolated chloroplast polyphenoloxidase in Beta vulgaris. Plant Physiology. 24(2): 1-15.

35. Bahls, L. R., Burkantis, R. and Tralles, S. (1992). Benchmark Biology of Montana Reference Streams. Department of Health and Environmental Science, Water Quality Bureau, Helena, Montana.

36. Magurran, A. E. (1988). Ecological Diversity and its Measurement. Chapman and Hall, London, 179 pp.

37. Ter Braak, C. J. F. (1986). Canonical correspondence analysis: A new eigen vector technique for multivariate direct gradient analysis. Ecology. 67: 11671179.

38. Mahmood, N. and Zafar M. (1990). Occurrence and abundance of four commercially important penaeid post larvae in the estuarine waters of Satkhira Bangladesh. Pakistan Journal of Industrial Research. 33 (3): 110114.

39. Ali, A., Sukanta, S. and Mahmood, N. (1985). Seasonal abundance of plankton in Moheskhali channel, Bay of Bengal. In Proceeding of SAARC Seminar on Protection of Environment from Degradation. 128-140.

40. Osore, M. K. W., Mwaluma, J. M., Fierset, F. and Daro, M. H. (2004). Zooplankton composition and abundance in Mida Creek, Kenya. Zoological Studies. 43 (2): 415-424.

41. Siokou-Frangou, I. (1996). Zooplankton annual cycle in a Mediterranean coastal area. Journal of Plankton Research. 18: 2203-223. 
42. Gilabert, J. (2001). Seasonal plankton dynamics in a Mediterranean hypersaline coastal lagoon: the Mar Menor. Journal of Plankton Research. 203: 207-217.

43. Vieira, L., Azeiteiro, U. M., Pastonnho, P. Re. R., Marques, J. C. and Morgado, F. (2003). Zooplankton distribution in a temperate estuary (Mondego estuary southern arm: Western Portugal). Acta Oecologica. 24: S163-S173.

44. Rajyalkshmi, T. (1973). The prawn and shrimp nursing areas on the estuaries and lakes on the east coast of India - A review and discussion. In Proceedings of Seminar on Mamilarllam and Alechanijeed, Fishery Madras, 42-56 pp.

45. Macnae. (1974). Mangrove Forest and Fisheries, FAO Rome.

46. Mahmood, N., Zafar, M. and Matin, A. K. M. A. (1990). Occurrence and abundance of apheid shrimp post larvae in the Satkhira estuarine systems, Bangladesh. Chittagong University Studies (Science). 14: 119125.

47. Hamid, R., Yusoff, F. M., Arshad, A., Kawamura, A., Nishida, S. and Ross, O. B. H. (2004). Spatial and temporal distribution of copepods in the Straits of Malacca. Zoological Studies. 43(2): 486-497.

48. Othman, B. H. R. (1988). Pelagic Copepod of Economic Exclusive Zone Area in the South China Sea. Paper present at 11th Malaysian Society of Marine
Science Seminar Thirty Years of

Marine Science Research and Development. Universiti Malaya, pp. 8-14.

49. Gajbhiye, S. N., Nair, V. R. and Desai, B. N. (1981). Diurnal variation of zooplankton off Versove (Bombay). Mahasagar-Bulletin of National Institute of Oceanography. 14(3): 173182.

50. Perumal, V. N., Rajkumar, M., Perumal, P. and Rajasekar, K.T. (2009). Seasonal variations of plankton diversity in the Kaduviyar estuary, Nagapattinam. Southeast coast of India. Journal of Environmental Biology. 30 (6): 10351046.

51. Hwang, J. S., Kumaret, R, Hsieh, C. W., Kuo, A. Y., Souissi, S., Hsu, M. H., Wu, J. T., Liu, W C., Wang, C. F. and Chen, Q. C. (2010). Patterns of zooplankton distribution along the marine, estuarine and riverine portions of the Danshuei ecosystem in Northern Taiwan. Zoological Studies. 49 (3): 335-352.

52. Raymont, J. G. (1976). Plankton and Productivity in the Oceans. Pergamon Press, Oxford.

53. Jordan, T. E., Correli, D.L., Miklas, J. and Weller, D. E. (1991). Long-term trends in estuarine nutrients and chlorophyll and short-term effects of variation in watershed discharge. Marine Ecology and Progress Series. 75:121-132. 